\title{
Smart Response Concept for Fire Emergency Response in Surabaya City
}

\author{
Fonita Andastry Bontang Sari \\ Faculty of Architecture,Design, and Planning \\ Institut Teknologi Sepuluh Nopember \\ Surabaya, Indonesia
}

\author{
Eko Budi Santoso \\ Faculty of Architecture, Design, and Planning \\ Institut Teknologi Sepuluh Nopember \\ Surabaya, Indonesia
}

\author{
Adjie Pamungkas \\ Faculty of Architecture, Design, and Planning \\ Institut Teknologi Sepuluh Nopember \\ Surabaya, Indonesia
}

\begin{abstract}
The city of Surabaya is one of the second major cities in Indonesia. At present the growth and development of the city of Surabaya is very rapid in various fields. Increased population density, the number of office building developments, residential areas, industries that are increasingly developing, causing vulnerability to fires. Fire events in the city of Surabaya tend to fluctuate. But the number of events is quite large, especially in 2017. So it is necessary to have innovative efforts to reduce losses due to fires in the city of Surabaya. This fire incident certainly gives a big loss not only materially but also casualties. In this case the Government of Surabaya has begun to implement smart city as one of the steps to deal with various problems in the city of Surabaya, one of which is fire. Through the concept of smart city, it is expected to help reduce losses caused by fires. In line with this, the aim of this research is to formulate a concept of smart fire response to reduce fire losses that occur and as an innovation in fire management. To support the implementation of the research, a triangulation analysis of stakeholders will be carried out (confirmation process from the formulation of researchers related to intelligent response concepts based on existing conditions and results of literature review of expert theories) which then results in stakeholder triangulation as the final result of this intelligent response concept formulation.
\end{abstract}

Keywords-Fire; management fire, smart response, smart fire response

\section{INTRODUCTION}

The city of Surabaya has an area of $\pm 326.81 \mathrm{~km}^{2}$ which is divided into 31 sub-districts and 131 sub-districts. The city of Surabaya is one of the big cities in Indonesia. Surabaya City ranks second as the Big City after the City of Jakarta. As a Big City Surabaya City has a high population density as seen from the population in the city of Surabaya based on the 2010 population census of $2,765,487$ inhabitants. At present the growth and development of the city of Surabaya is very rapid in various fields. Increased population density, the number of office building developments, residential areas, industries that are increasingly developing, causing vulnerability to fires. In line with the increasing population, it will increase the need for shelter, resulting in a tendency to increase buildings which then increases the potential for fire threats in the city of Surabaya [1].

Fire events in the city of Surabaya occur repeatedly every year. In 2012 there were 573 fire incidents, in 2014 there were 596 fire incidents, in 2015 there were 600 fire incidents. But there was a decrease in fire events in 2016, where only 300 fire incidents occurred in the city of Surabaya. But the occurrence of kebakaaran has increased throughout 2017, there were 321 fire incidents in the city of Surabaya. Based on the number of fire incidents that occurred throughout 2017, the losses were quite large [2].

Losses due to fire incidents that occurred in the city of Surabaya throughout 2017 from 321 total fire incidents (January-November period) amounting to 18.2 billion rupiah. The fire burned 82 houses and 14 factories and spent as much as 225 land of grass land. While losses based on fatalities from fires were known as 21 people were injured and 1 person died. In an effort to reduce fire losses, the Surabaya City Government implemented e-government that helped the process of managing regional development and community services. E-government also has a system such as a disaster alert system that can help the government in monitoring the occurrence of traffic accidents, fires, fallen trees. This system makes it easier for the government to find the location of the disaster. For example, if a fire occurs, the PMK officer can search for the nearest water source from the location of the fire and the dashboard of his car.

This E-Gov is part of an effort to implement the smart city concept. At present the city of Surabaya is being aggressively developing smart cities. According to Nijkamp et al (2009) states that smart cities are cities that are able to use human resources (HR), human capital, and modern telecommunications infrastructure to realize sustainable economic growth and high quality of life. According to Cohen (2010) the main dimensions of the smart city are 6, including smart governance, smart mobility, smart environment, smart people, smart economy, and smart living. From the 6 dimensions that exist, in its application each city can focus on one dimension that exists. For now the city of Surabaya has tried to apply the concept of smart city by providing public services known as command centers that can be accessed by the public through the complaint number 112. As well as known there are also e-dishub applications related to transportation in the city of Surabaya, which is also a efforts to realize smart mobility [3].

In line with this, there is currently no research related to fire management based on smart mobility. The principle of smart mobility can be applied to optimize the response to disaster 
reports / news. Based on the principle of smart mobility a "smart response" will be formulated for a fire disaster in the city of Surabaya. Therefore this study focuses on formulating the concept of quick response to fire in the city of Surabaya. Based on this, this study wants to find out how the right quick response concept is based on the principle of smart mobility for fire disaster emergency response as an effort to reduce losses due to fire disasters which are still a threat due to constraints of fire fighting facilities in reaching fire locations.

\section{RESEARCH METHODS}

There are several stages in this study, first is to compare the results of interviews with stakeholders generated through an in-depth interview process which is then analyzed using comtent analysis. The results of content analysis then become input in the next stage to formulate the concept of intelligent response to fire in the city of Surabaya. The analysis results in the form of a list of potential and problems faced in the effort to handle fires faced by the Surabaya City government.

At the next stage the potential results and problems are compared with the intelligent response criteria that have been prepared based on a collection of expert theories and existing existing conditions in the city of Surabaya. This stage is done by making a comparative and triangulation table (where the results of the concept of intelligent fire response concept will be confirmed again to the relevant stakeholders), then the final results are obtained in the form of "intelligent fire response concept in Surabaya City".

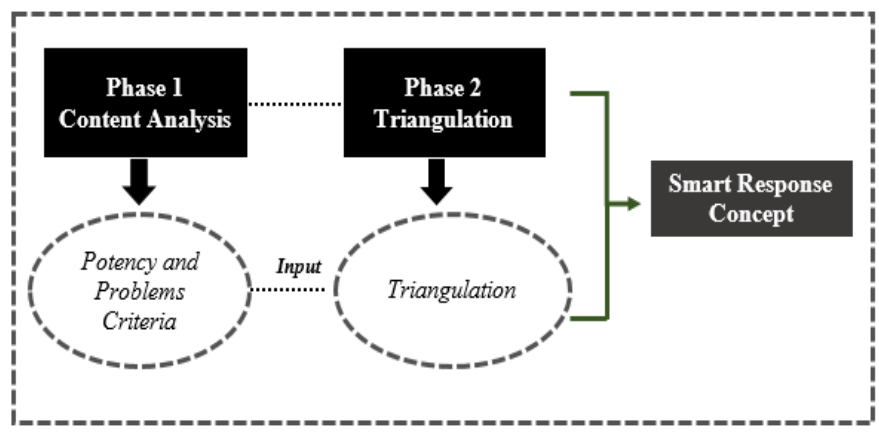

Fig. 1. Research Methods

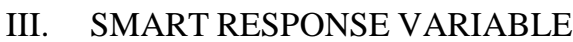

Based on the results of library synthesis from several theories related to this study, it was found that several variables that could support this study included the following:

TABEL I. RESEARCH VARIABLES

\begin{tabular}{|c|c|c|}
\hline Theory & Indicator & Variable \\
\hline \multirow{12}{*}{$\begin{array}{c}\text { Smart } \\
\text { Response }\end{array}$} & \multirow{3}{*}{ Response Time } & Time to Recieve News \\
\hline & & Travel Time \\
\hline & & Tools Preparation Time On Site \\
\hline & \multirow{3}{*}{$\begin{array}{l}\text { Search for } \\
\text { Victims }\end{array}$} & Number of Victims Found \\
\hline & & Number of Search Personnel \\
\hline & & Availability of Search Tools \\
\hline & \multirow{3}{*}{ Rescue Victims } & Number of Vitims Rescue \\
\hline & & Number of Rescue Personnel \\
\hline & & Availability of Rescue Tools \\
\hline & \multirow{3}{*}{$\begin{array}{c}\text { Evacuation } \\
\text { Victims }\end{array}$} & Number of Victims Evacuation \\
\hline & & Number of Evacuation Personnel \\
\hline & & Availability of Evacuation Tools \\
\hline
\end{tabular}

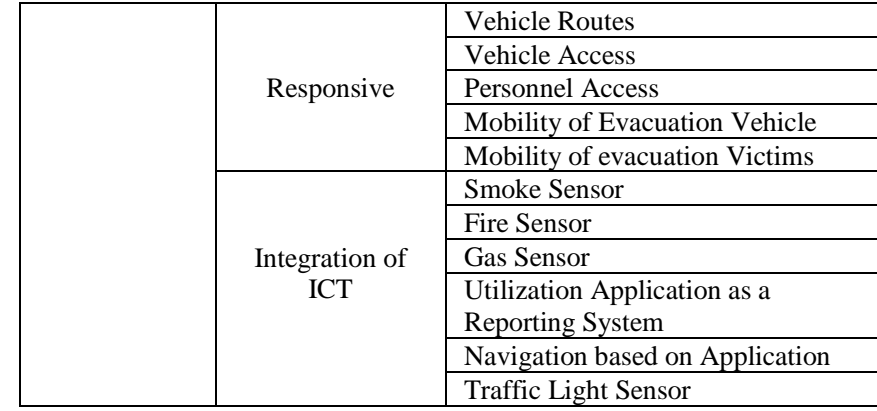

\section{RESULTS AND DISCUSSION}

\section{A. Ilustration Tables of Comparative}

The formulation of this concept is based on the potential and problems faced in handling fire disasters in the city of Surabaya and the criteria that have been formulated from several experts. There are 11 point of criteria from this study:

1. Use of Technology in an effort to extinguish fires

2. Emergency response (response quickly, medium and full)

3. Periodic skills training for personnel

4. Technology-based Communication Network (Communication Protocol, Use of Social Media as a Communication Tool, Data Interface Emergency Access)

5. Sensor Technology (Use of Remote Sensing, Unmanned Vehicles, Sensing Integration, Remote Communication, Sensors Improved platform reliability, use of robotic technology as search and rescue personnel, development of forensic timelines based on stationary sensors that provide information throughout incidents, synchronization with sensors brought by residents, the use of social media as a tool included as a source of data that can be mined and utilized)

6. Simulation Technology (Simulation for training and education, simulations for outreach and continuation)

7. Implementation of Sensor Technology

8. Standardize the performance of sensor environments that depend on data

9. Smart Building and Sensor Robot Technology

10. Smart Fire Fighting Equipment and Robot Mapping Technology

11. Smart Outage Personnel Regulations

And then to formulate the concept, potency and problems, criteria smart response and existing condition will be comparaed to analyze and then will be confirmed to stakeholders. The ilustration of this proses can be seen this below: 


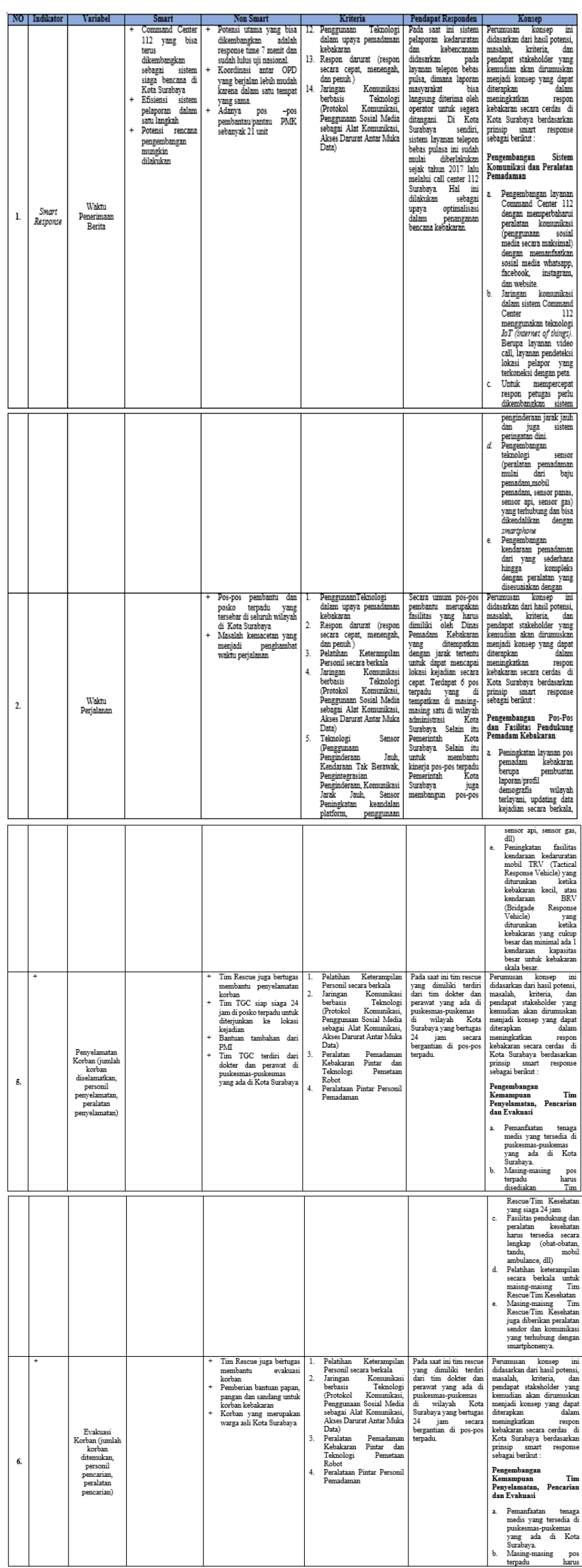

Fig. 2. Comparative Table formulation of Smart Response Concepts
The picture above shows the process of drafting the concept of fire rapid response that will be applied in the city of Surabaya. The formulation process will be explained as follows: 1) In the first column explain the indicators of this research, namely rapid reponse; 2) then the second column explains each research variable; 3) in the next column will be compared between the results of potential fire handling problems in the city of Surabaya, the results of rapid response criteria, and the results of interviews with stakeholders and then the appropriate response concept can be formulated and can be applied in the city of Surabaya.

Based on the above process from the comparative table, the formulation of intelligent response concepts can be applied that can be applied in emergency response to fire in the city of Surabaya. The formulation of this concept is based on the results of potential and problems faced and intelligent response criteria from the results of the study of several theories and interviews with relevant stakeholders. There are 12 main concepts that have been formulated in the study can be seen in the pictures below:

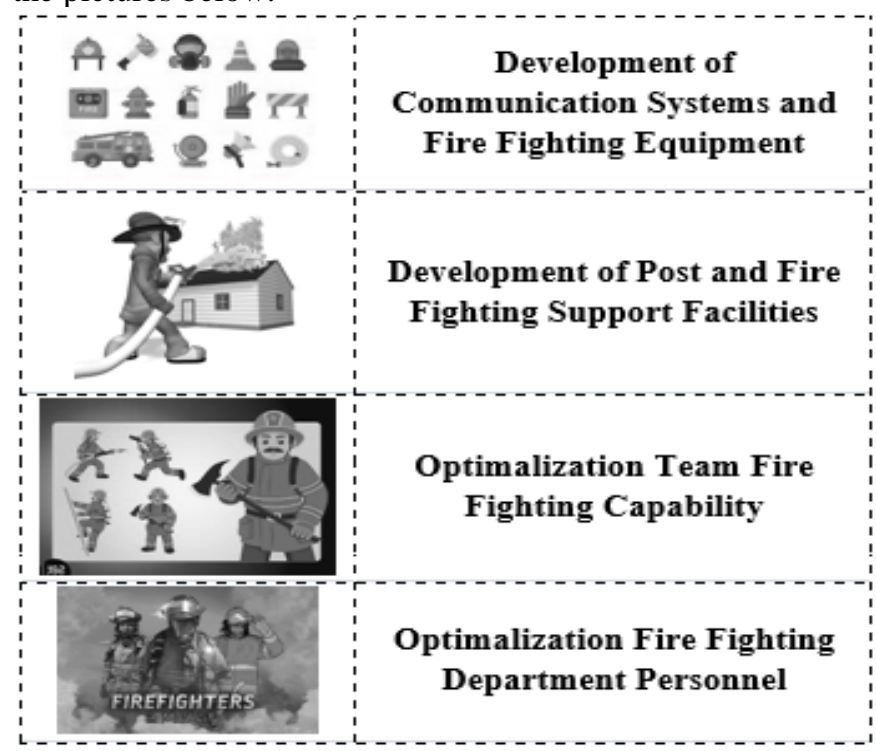

Fig. 3. Smart Response Concept Point 1 to 4

From the picture above, it is known that there are 4 concepts out of a total of 12 main concepts that can be developed in rapid fire responses in the city of Surabaya. This concept consists of : 1) Development of Communication Systems and Fire Figthing Equipment; 2) Development of Post and Fire Fighting Support Facilities ; 3) Optimalization Team Fire Fighting Capability; 4) Optimalization Fire Fighting Departemen Personnel. 


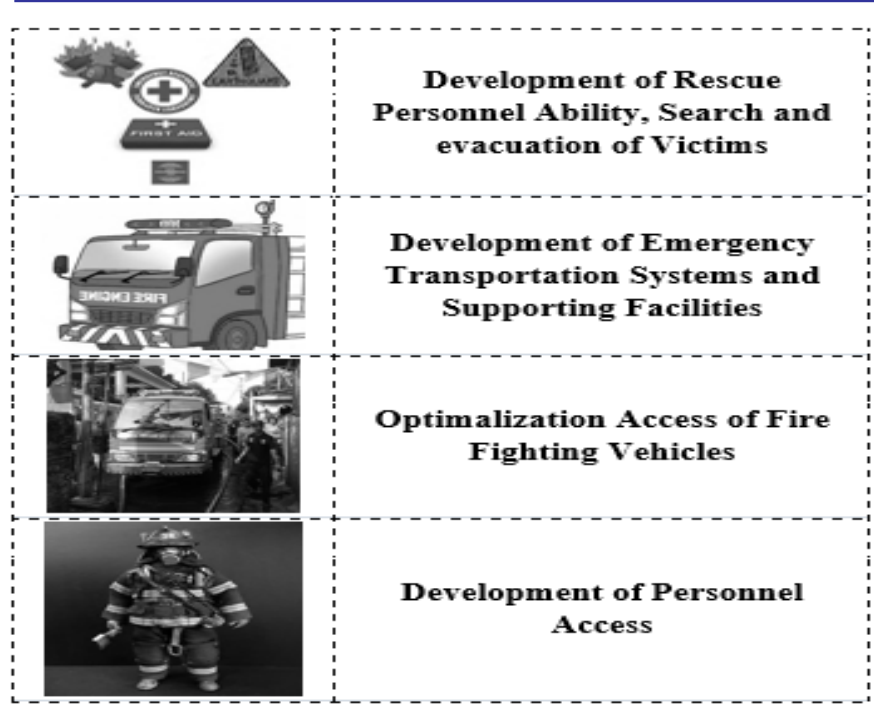

Fig. 4. Smart Response Concept Point 5 to 8

From the picture above, it is known that there are 4 concepts out of a total of 12 main concepts that can be developed in rapid fire responses in the city of Surabaya. This concept consists of : 1) Development of Rescue Personnel Ability, Search and Evacuation Victims; 2) Development of Emergency Transportation Systems and Supporting Facilities; 3) Optimalization Access of Fire Figthing Vehicles; 4) Development of Personnel Access.

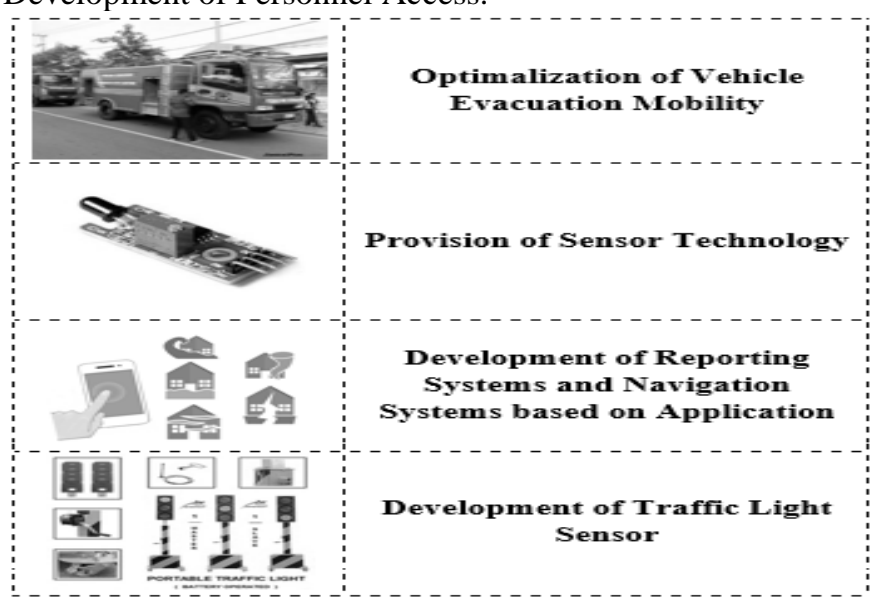

Fig. 5. Smart Response Concept Point 9 to 12

From the picture above, it is known that there are 4 concepts out of a total of 12 main concepts that can be developed in rapid fire responses in the city of Surabaya. This concept consists of : 1) Optimalization of Vehicle Evacuation Mobility; 2) Provision of Sensor Technology; 3) Development of Reporting Systems and Navigation Systems based on Application; 4) Development of Traffic Light Sensor.

\section{CONCLUSSION}

There are 12 main concepts of Smart Response Fire Fighting from this study. This concept consists of : 1) Development of Communication Systems and Fire Figthing Equipment; 2) Development of Post and Fire Fighting Support Facilities ; 3) Optimalization Team Fire Fighting Capability; 4) Optimalization Fire Fighting Departemen Personnel, 5) Development of Rescue Personnel Ability, Search and Evacuation Victims; 6) Development of Emergency
Transportation Systems and Supporting Facilities; 7) Optimalization Access of Fire Figthing Vehicles; 8) Development of Personnel Access, 9) Optimalization of Vehicle Evacuation Mobility; 10) Provision of Sensor Technology; 11) Development of Reporting Systems and Navigation Systems based on Application; 12) Development of Traffic Light Sensor.

\section{ACKNOWLEDGMENT}

Thank you to all the respondents, stakeholders, and my mentors for all their help while compiling this journal. I am also very grateful to all agencies involved in assisting in the preparation of this journal including the Command Center 112 Surabaya, Surabaya City Police, Surabaya City Fire Department, Surabaya City Transportation Department and also Surabaya City Disaster Management And Community Protection Department which have been very helpful and contributed data in this study. I also thank my parents and all my friends who supported me to finish this journal to the end.

\section{REFERENCES}

[1] Bappeko Kota Surbaya. 2018. "Rencana Pembangunan Jangka Menengah Kota Surabaya Tahun 2016-2021".

[2] Rahmawati, D, dkk. 2016. "Participatory Mapping for Urban Fire Risk Reduction in High Density Urban Settlement". Procedia. Social and Behavioral. vol 227. pp. 395-401.

[3] Caragliu, A. Del Bo,C. Nijkamp, P. 2009. "Smart Cities in Europe". 3rd Central European Conference in Regional Science-CERS.

[4] Albino, V. Umberto, B. Rosa, 2015. "Smart Cities: Definitions, Dimensions, Performance, and Initiatives. Journal of Urban Technology. Vol 1. pp. 3-21. http://dx.doi.org/10.1080/10630732.2014.942092 accessed on March 13, 2018.

[5] Saraswati, FD, and Cahyono, B,A. 2017. "Analisis Daerah Resiko Bencana Kebakaran di Kota Surabaya Menggunakan Sistem Informasi Geografis". Jurnal Teknik. vol 6;2. pp. 1. ITS.

[6] Larasati, K, D, dkk. 2016. "Penerapan Participatory Mapping untuk Mewujudkan Capacity Building Dalam Mengurangi Resiko Bencana Kebakaran”. Jurnal Teknik. ITS

[7] Sariffudin, S. 2015. "Peluang Pengembangan Smart Mobility untuk Mewujudkan Kota Tangguh di Kota Semarang. Jurnal Teknik Perencanaan Wilayah \& Kota. Vol 36. pp. 32-38.

[8] Nurulandari, F.S. 2016. Kajian Mitigasi Bencana Kebakaran di Permukiman Padat (Studi Kasus: Kelurahan Taman Sari, Kota Bandung). Jurnal INFOMATEK. vol 18. Universitas Pasundan.

[9] Hertfordshire Fire and Rescue Service. 2017. Final Report. "SMART Firefighting". England.

[10] Grant, C. Hamins, A. Bryner, N, Jones, A, and Koepke, G. 2015. NIST Special Publication 1191. "Research Roadmap for Smart Fire Fighting". National Institute of Standars and Technology. 